\title{
THE SYSTEM OF CIVIL PROCEDURAL RELATIONS
}

\section{Didenko L. V.}

\section{INTRODUCTION}

As with other areas of law (such as labor or civil), the system of civil procedural relations is a set of legal relations in the field of justice in civil cases, so their classification by many features is necessary. In spite of this, the problem of defining the system of civil procedural relations has not acquired a special interest of scientific, theoretical and scientific-practical interest to this day. Domestic scientists who in one way or another address this issue, use works dating back to the Soviet era. There have been very few studies conducted within the framework of the development of domestic legal institutions.

The urgency of the analysis of this problem can be expressed in the following directions: first, the proper definition and classification of civil procedural relations guarantees the effectiveness of the procedural rights of citizens secured and guaranteed by the current legislation; secondly, a situation in which a highly-researched institute of civil procedural relations generally has separate elements that are actually outside the attention of scholars is unacceptable. Therefore, the low level of scientific development and the importance of this issue for the theory of civil procedural relations generally determine the need to study the system of civil procedural relations.

However, despite the substantial amount of theoretical material on civil procedural relations, the issue of their system is still poorly understood, which makes the current study relevant.

\section{Concepts of research of the system of civil procedural relations}

A system is an order that is predetermined by the correct, systematic arrangement and interconnection of parts of something, or an established, accepted order $^{1}$. That is, the system of civil procedural relations is a certain set of its components, characterized by mutual connection and a certain order. Elements of systems of any social relations are their varieties. In other words, the study of the system of civil procedural relations involves establishing their varieties, as well as the relationships between them.

\footnotetext{
${ }^{1}$ Великий тлумачний словник сучасної української мови (з дод. і допов.) / уклад. і голов. ред. В. Т. Бусел. К.; Ірпінь : ВТФ “Перун”, 2005. С. 1320.
} 
The analysis of the scientific literature showed that, at present, studies of the system of civil procedural relations were not actually carried out after the proclamation of Ukraine's independence ${ }^{2}$. Textbooks and monographs on civil procedural law reveal the essence of civil procedural relations, first of all, taking into account their concepts, features, subjects, object, content and grounds of origin ${ }^{3}$. In their turn, researchers of directly civil procedural relationships are also largely oblivious to the disclosure of this issue. The most complete question was revealed in the work of A.L. Pascar ${ }^{4}$, however, in this case, the question under study requires a little deeper analysis.

First of all, note the work of the said scientist in view of the qualitative study of the evolution of scientific thoughts on the system of civil procedural relations. Thus, the researcher noted that the issue of the unity of civil procedural relations was investigated even before the revolutionary processualists. For example, E.O. Nefediev wrote: "In the process as regulated by the law of activity, there is unity and integrity. If there are all conditions for the process to occur, then the process itself emerges as a whole" . From this point, we can conclude that the civil process is a set of interrelated actions of its members. At the same time, all activities performed by them are regulated by law. This, on the one hand, ensures unity and, on the other, regulates the behavior of participants in the process. In the same period E.V. Vaskovsky, exploring the structure of relations that arise in the civil process, noted that they are united by a common element and form a whole 6 . That is, all the activities of the parties to the civil process is a set of civil-procedural relations of the participants, which function in unity to achieve a common goal. However, as A.L. notes. Pascar ${ }^{7}$, despite the high level of scientific attention to the unity of civil procedural relations on the part of the procedural scholars of the time, the study of the structure and factors at the expense of which this unity was ensured, was not carried

\footnotetext{
2 Диденко Л. В. Сущность системы гражданских процесуальних правоотношений. Право и политика. 2015. Спецвыпуск. С. 73.

${ }^{3}$ Васильєв С. В. Цивільний процес України : навчальний посібник. К. : “Центр учбової літератури", 2013. С. 39-42; Кілічава Т. М. Цивільне процесуальне право : навч. посіб. К. : Центр учбової літератури. 2007. С. 31-37.

${ }^{4}$ Паскар А. Л. Система цивільних процесуальних правовідносин. Науковий вісник Чернівеиького університету. 2011. Вип. 578. С. 83-87.

5 Гражданский процесс: хрестоматия: учеб. Пособие / под ред. проф. М. К. Треушникова. 2-е изд. испр. и доп. М. : ОАО “Издательский Дом “Городец”, 2005. C. $95-96$.

${ }^{6}$ Васьковский Е. В. Курс гражданского процесса. Том 1. Субъекты и объекты процесса, процессуальные отношения и действия. М. : Издание Бр. Башмаковых, 1913. C. $685-686$.

${ }^{7}$ Паскар А. Л. Система цивільних процесуальних правовідносин. Науковий вісник Чернівецького університету. 2011. Вип. 578. С. 83.
} 
out at that time. Note that such a situation can be observed today, because unity and systematicity is defined as one of the main features of civil procedural relations by virtually all researchers, however, the essence of this "systematic" is beyond their attention.

In the era of Soviet law, as noted by A.L. Pascar ${ }^{8}$, the concept of a single civil procedural relationship has remained relevant. Among the researchers of the time, the examples of V.P.P. Mozolina ${ }^{9}$ and D.R. Dzhalilova ${ }^{10}$, from which we can distinguish the following features of the current understanding of the system of civil procedural relations:

1) there are no separate procedural relations in the civil process, since in such a case, the civil procedural relationship loses its integrity by splitting into separate parts;

2) a civil procedural relationship can exist only in the unity of activity of all subjects, and separate relations of the court with the plaintiff, with the defendant, with other participants of the process represent only certain aspects of a single civil procedural relationship in a particular case;

3) each of the parties to a single civil legal process is distinguished by its specific object, content, legal grounds of origin and termination.

That is, the foundations of the modern institute of civil procedural relations were laid already in the Soviet period. The system of civil procedural relations was considered solely in the unity of elements, that is, there were no classifications of varieties of civil procedural relations - there was a single legal relationship, which included the whole set of relations between the court and participants in the trial. Given their multiplicity and unity, disclosure of their structure was considered inappropriate. However, it is noted that not all researchers agreed with this concept, but these ideas were developed only in the following decades.

A.L. Pascar ${ }^{11}$ notes that criticism of the concept of a single civil procedural relationship has taken place both in Soviet times and since the independence of Ukraine, and as an example the following argument is given:

1) M.B. Zader pointed out that in each particular case there were a number of numerous legal links between court and plaintiff, between court

\footnotetext{
${ }^{8}$ Паскар А. Л. Система цивільних процесуальних правовідносин. Науковий вісник Чернівецького університету. 2011. Вип. 578. С. 83.

${ }^{9}$ Мозолин В. П. О гражданско-процессуальном правоотношении. Сов. государство и право. 1955. № 6. С. 56.

10 Джалилов Д. Р. Гражданское процессуальное правоотношение и его субъекты. Душанбе, 1962. С. 34.

${ }^{11}$ Паскар А. Л. Система цивільних процесуальних правовідносин. Науковий вісник Чернівеиького університету. 2011. Вип. 578. С. 84.
} 
and defendant, etc. (that is, between the parties), aimed at achieving procedural goals. However, the totality of these relationships does not appear to be a single, albeit complicated legal relationship ${ }^{12}$. That is, despite the systematic nature of civil procedural relationships, they are still interdependent. This means that the occurrence of some relationships causes the termination of others. The same processes can occur in the case of a change of legal relationship. In other words, specific civil procedural relationships as elements of a system cannot exist separately from other elements;

2) already in times of independence and, accordingly, formation of the national institute of civil procedural relations, V.V. Komarov argued that in the process of civil proceedings there are a number of legal relationships, which are interconnected, though independent in content, because they are inherent in the complex of civil rights and responsibilities, the specific composition of the subjects, the grounds and time of their occurrence, as well as termination ${ }^{13}$. That is, each case is subject to a series of civil procedural relations between the court and other entities. Legal relations are different in content, they may be different in the subject composition, rights and obligations of the participants, etc., so they cannot be considered as just one elemental legal relationship. Accordingly, the very concept of a single civil procedural relationship was further developed in Soviet times.

The period from the birth of the Soviet institute of civil procedural relations to the formation of the corresponding domestic institute is characterized by constant disputes of scientists on this subject. In fact, by the 1960s, two basic models of understanding of the system of civil procedural legal relations were formed, about which most scientific discussions were conducted:

1) a model of a single legal relationship;

2) a model of a multiplicity of civil procedural legal relations, each characterized by its own content, subject composition, object, rights and obligations of the parties, etc.

However, it was already clear at the time that the resolution of existing disputes was possible only through the further development of the Institute and the improvement of scientific formulations. Therefore, in the 1960s and 1970s, another model emerged, which was a compromise for both parties. Representatives of the new concept focused on the constituent parts of the

12 Зейдер Н. Б. Гражданские процессуальные правоотношения. Саратов : СГУ, 1965. С. 11.

${ }^{13}$ Цивільне процесуальне право України : підручник для юрид. вузів і фак. / В. В. Комаров, В. А. Бігун, П. І. Радченко та ін. ; за ред. В. В. Комарова. Харків : Основа, 1992. C. 51. 
procedural legal relationship and their interconnection, and emphasized the existence of a complex civil procedural legal relationship, which encompassed a system of individual elementary legal relations ${ }^{14}$. This model can be explained as follows: the scientists concurrently agreed with both the unity of civil procedural relations and the expediency of allocating a number of elementary procedural relations within each of them.

That is, it was considered that a single procedural relationship consists of a series of elementary civil procedural relationships, each of which, at different stages, is combined into a single whole. Such a concept, as A.L. notes. Pascar, existed until the early 80 's of the twentieth century ${ }^{15}$. Its importance for the further development of the system of civil procedural legal relations is that, unlike its predecessors, the researchers of this group directed their activity to the study of elements - elementary civil legal relations. At the same time, they did not dispute the unity of the civil procedural relationship, and the basic idea was to form a complex civil procedural relationship out of the simple relations.

Another concept, dating from that period, is the model of the "system of civil procedural relations", which appeared on the basis of provisions developed by supporters of the concept of a single and complex civil procedural relationship ${ }^{16}$. As with the concept of a complex civil legal process, the new model was designed to address the shortcomings and gaps of previous concepts and provide a more modern explanation of the links between civil procedural relationships. Both concepts have not existed in this form for a long time and have always been the subject of debate. The model of "system of civil procedural relations" is still considered to be a more advanced version of the concept of "complex civil procedural legal relations", since its content was clear connections and the nature of the interaction of numerous elementary civil legal relations.

In fact, the model of the "system of civil procedural relations" is the concept that is relevant today. However, it should be borne in mind that it has also come a long way in evolution. At the scientific level ${ }^{17}$, it is considered that the essence of this concept has been fully and thoroughly explained by N.O. Chechnya. The researcher found that civil procedural

${ }^{14}$ Гурвич М. А. Гражданские процессуальные правоотношения и процессуальные действия. В 3-х т. Том 3: Вопросы гражданского процессуального, гражданского и трудового права. М. : ВЮЗИ, 1965. С. 88-92.

${ }^{15}$ Паскар А. Л. Система цивільних процесуальних правовідносин. Науковий вісник Чернівецького університету. 2011. Вип. 578. С. 84.

${ }^{16}$ Паскар А. Л. Система цивільних процесуальних правовідносин. Науковий вісник Чернівеиького університету. 2011. Вип. 578. С. 84-85.

${ }^{17}$ Паскар А. Л. Система цивільних процесуальних правовідносин. Науковий вісник Чернівеиького університету. 2011. Вип. 578. С. 85. 
relations always exist as an integral part of a certain system, that is, they are in mutual and obligatory connection with one another. No procedural legal relationship can exist and develop separately, by itself, without further, necessarily subsequent relations, or without the relations that precede them in time ${ }^{18}$. In other words, civil procedural relations cannot exist separately, each by itself, and individual elementary civil procedural relations are interconnected and exist solely within the framework of a common system.

Over time, more and more scientists have become supporters of this theory. There are still controversial points, in particular, a number of scholars did not support the term "system" ". However, the theory of domestic law, the research institute came into being as a system. A.L. Pascar explains that the term system means a whole made up of parts, that is, a set of elements that are in relationship and bond with each other, forming a certain integrity and unity. Moreover, the "system" is characterized in view of the main features: elements - components; structure - the connection between the forming elements; integrity ${ }^{20}$. From this, we can conclude that the formulation of "system" is still successful for civil procedural relations, because it fairly and clearly defines the nature and nature of the relations of the structural elements of the studied institute. It is also noted that during the period under review, the scientific debate was not to refute the ideas of unity of civil procedural relations or scientific positions of each other, but to form a correct understanding whereby this unity was ensured. Scholars who have been in favor of a single civil procedural relationship have argued that "unity" means one, and therefore, the selection of elements in this category is inappropriate. Accordingly, "systemic" concepts were based on the fact that civil process as a judicial system is a system of civil procedural relations, the unity of which is the link between them. At the same time, each legal relationship in the system is subject to a common purpose and is consistent with it.

So, let's summarize the research of the development of scientific ideas for understanding the essence of the "system of civil procedural relations". The main models in the pre-Soviet and Soviet periods were:

1) a model of a single legal relationship;

2) a model of a multiplicity of civil procedural relationships, each characterized by its own content, subject composition, object, rights and obligations of the parties, etc.;

3) model of complex civil procedural relationship;

${ }^{18}$ Чечина Н. А. Гражданские процессуальные отношения. Л. : Изд-во Ленингр. унта, 1962. С. 56-63.

${ }^{19}$ Гурвич М. А. Основные черты гражданского процессуального правоотношения. Советское государство и право. 1972. № 2. С. 32.

${ }^{20}$ Паскар А. Л. Система цивільних процесуальних правовідносин. Науковий вісник Чернівещьького університету. 2011. Вип. 578. С. 85. 
4) model of the system of civil procedural legal relations.

Each of these categories has in one way or another influenced the development of the following, so it is not advisable to analyze their impact on the current state of the research institute.

\section{Modern model of the system of civil procedural legal relations}

Today, the most relevant and relevant is the most recent concept - the model of the system of civil procedural relations. In the scientific literature, this term is predominantly found. However, in the post-Soviet period, the study of the essence of the system of civil procedural relations in our country actually stopped. Among the adherents of this model can be distinguished, in particular, the previously mentioned scientist V.V. Komarov, who notes that any system is described by reference to its three main components: elements, structure (connection between elements) and integrity, and, accordingly, supports the very model of the system of civil procedural relations ${ }^{21}$. In this case, integrity is a prerequisite for the existence of a system of civil procedural relations. That is, the whole set of civil procedural relations must be united and be one. Each legal relationship cannot exist on its own. A.L. Pascar explains this in the following example - there are separate independent civil procedural relationships between the court and the participants in civil procedural relations. At the same time, having first arisen between the court and the person who appealed to the court for protection, they become the legal basis for the emergence of procedural legal relations between the court and other participants in civil proceeding ${ }^{22}$. That is, individual civil legal relationships do not arise, change or terminate on their own - they are part of a single system, and their occurrence, termination or change is solely due to the emergence, termination or alteration of other civil legal systems integrated with them.

Based on the works of domestic scientists ${ }^{23}$ we will conclude that the modern model of the system of civil procedural relations is characterized by the following features:

1) civil procedural relations are regarded as a system of specific, individualized legal relationships that develop in the course of a civil case from its occurrence to termination;

21 Проблемы науки гражданского процессуального права / [B. В. Комаров, В. А. Бігун, В. В. Баранкова та ін.] ; под ред. проф. В. В. Комарова. Х. : Право, 2002. C. 53.

${ }^{22}$ Паскар А. Л. Система цивільних процесуальних правовідносин. Науковий вісник Чернівецького університету. 2011. Вип. 578. С. 85.

23 Проблемы науки гражданского процессуального права / [В. В. Комаров, В. А. Бігун, В. В. Баранкова та ін.]; под ред. проф. В. В. Комарова. Х. : Право, 2002. C. 53. 
2) civil procedural relationships form a system of closely interrelated and interrelated legal relationships;

3) the system of civil procedural legal relations consists of a set of relatively independent legal relationships that differ from each other on grounds of origin, subject composition, content, object;

4) none of the legal relationships that are in the system can exist in isolation from the others.

From these features, it can be noted that the content of the concept clearly demonstrates the use of all historical background since pre-revolutionary times. This model is much clearer and more formulated than all previous ones ${ }^{24}$. Let's agree with A.L. Pascar, that each of the analyzed models should not be considered in their contradictions, but more expedient to be understood as complementary and logical evolutionary path ${ }^{25}$. Moreover, the recent development and support of scientists, who received the most recent model, shows that today the system of civil procedural relations is indeed the most successful expression of their structure, among all the existing alternatives.

Therefore, we formulate the following definition: the system of civil procedural legal relations is an order of closely interrelated and mutually related relatively independent legal relations that differ from each other on grounds of origin, subject composition, content, object and cannot exist in isolation from others, between which establishes specific, individualized legal relationships that develop in the course of a civil case from its occurrence to termination.

At the same time, it should be understood that the system of civil procedural relations is independent and individual for each specific case. This can be understood, in particular, by the fact that the cases differ in subject composition, content, object, and there are individual legal links between the elements of the system. The analysis of the rules of the CPC of Ukraine $^{26}$ shows the complexity of the procedure of civil proceedings in the civil process. This causes a variety of legal relationships between the court and the parties, between the parties, between the parties and third parties, between the court and third parties, etc. Therefore, in the administration of justice in civil cases, all the diversity of such relationships is manifested.

At the same time, the individualized nature of the composition of the system and the large number of possible civil procedural relations

${ }^{24}$ Діденко Л. В. Система цивільних процесуальних правовідносин. Visegrad journal of human rights. 2016. № 614. Р. 32.

${ }^{25}$ Паскар А. Л. Система цивільних процесуальних правовідносин. Науковий вісник Чернівецького університету. 2011. Вип. 578. С. 86.

${ }^{26}$ Цивільний процесуальний кодекс України: Закон України від 18.03.2004 № 1618-IV. Відомості Верховної Ради України. 2004. № 40-41, 42. Ст. 492. 
necessitate their successful classification for the purpose of ordering, as well as a better understanding. An analysis of the scientific literature has shown that this issue is not actually being addressed properly. There are only a few examples of the scholarly attention to the issue of classification of types of civil procedural relations. One of the most successful examples is the concept formulated by the authors of the textbook "Theoretical Problems of Civil Procedural Law", as amended by M.M. Yasinka ${ }^{27}$. Scientists classify civil procedural relations into the following types:

1. By the nature of the relationship between the subjects of the process, civil procedural relations are divided into:

1) the principal is the relationship between the court and the parties to the process (for example, filing a claim by the plaintiff, setting out the requirements for the subject matter of the dispute and their justification);

2) derivatives - interaction of the court with others, persons involved in the case (in particular, the legal relationship between the court and the witnesses);

3) auxiliary - relations between the court and other participants in the process that contribute to the administration of justice (including legal relations that arise between the court and experts, translators, the secretary, etc.);

2. By the nature of their interaction, civil procedural relations are divided into:

1) competitiveness relations - competitiveness relations are any civil procedural relations during civil proceedings, under which the parties have equal rights over the exercise of all procedural rights and obligations provided for by law, and each party must prove the circumstances relevant to the case and to which it refers as a basis for its claims or objections;

2) relations of cooperation - as an example of relations of cooperation we note the pre-judicial settlement of the dispute, which can be carried out voluntarily by the parties;

3) management relations - such legal relationships, in particular, are those which provide for the enforcement of court decisions;

3. Depending on the functions and tasks performed, civil procedural relationships are classified into:

1) regulatory - such legal relations are legal relations regarding the settlement of a dispute in a case involving a judge;

2) security:

27 Теоретичні проблеми цивільного процесуального права : підручник / М. М. Ясинок, М. П. Курило, О. В. Кіріяк, О. О. Кармаза, С. І. Запара та ін.; за заг. ред. д.ю.н. професора М. М. Ясинка. К. : Алерта, 2016. С. 168-169. 
- restorative - for example, legal relations concerning the restoration of the civil capacity of an individual in the order of separate proceedings;

- punitive - failure to comply with a judgment is grounds for liability established by law;

- Compensation - for example, a witness is entitled to compensation for costs associated with subpoena;

4. According to the division of rights and responsibilities between the subjects of civil procedural legal relations, the latter are divided into:

1) unilateral - yes, justice in Ukraine is exercised exclusively by the courts, and therefore civil procedural legal relations for the administration of justice are unilateral, since the rights belong exclusively to the courts;

2) bilateral - any legal relationship between the court and the parties, between the parties, between the court and third parties, between the parties and third parties;

5. According to the presence and nature of the subjects' interest, civil procedural relations can be classified into:

1) the relationship between the court and persons having a material interest in the results of the case;

2) the relationship between the court and persons having a procedural interest;

3) the relationship between the court and individuals who are not interested in the outcome of the case, but which contribute to the administration of justice (experts, translators, secretary, etc.).

Such a variety of criteria is, above all, indicative of the feasibility of the conclusions drawn in the work - any system of civil procedural relationships can indeed involve as many elementary legal relationships as possible. In this case, the composition of the system will be different and characterized by unique features in each case.

S. Ya. Fursa, highlighting the same criteria for the classification of civil procedural relations, similar varieties and thus explaining their essence ${ }^{28}$. This is the basis for the conclusion that today the issue of the system of civil procedural relations is characterized by the same vision on the part of different scholars. At the same time, the existence of each of the selected types of civil procedural relations is confirmed in the rules of the CPC of Ukraine $^{29}$. Thus, the existence of the main, derivative and auxiliary civil procedural relations is evidenced by the subject composition. As we have

${ }^{28}$ Фурса С. Я. Цивільний процес України: академічний курс : підручник для студ. юрид. спец. вищ. навч. закл. - К. : Видавець Фурса С.Я., КНТ, 2009. С. 134-135.

29 Цивільний процесуальний кодекс України : Закон України від 18.03.2004 № 1618-IV. Відомості Верховної Ради Украӥни. 2004. № 40-41, 42. Ст. 492. 
established, the court is the obligatory subject of civil procedural relations. Chapter 4 of the Code is devoted to regulating the issue of the parties involved, that is, the persons involved in the case. The main civil procedural legal relationship arises between the court and such persons. In paragraph 3 of this chapter, a number of articles regulate the procedural status of persons facilitating the trial and settlement of a case. Witnesses are an example of such persons. However, other litigants who contribute to the administration of justice may also be involved in civil legal proceedings. Article 65 of the CPC of Ukraine refers to such persons as an Assistant Judge, Registrar, Court Clerk, Witness, Expert, Law Expert, Translator, Specialist. The court and such persons have ancillary civil procedural legal relationship.

By the nature of the interaction, civil procedural relations are customary to be divided into competitiveness relations, cooperation relations and management relations. Competitiveness, as their name implies, arises in civil proceedings. As set out in Article 12 of the CPC of Ukraine ${ }^{30}$, competitiveness relations are characterized by the following features: 1) each party must prove the circumstances relevant to the case and to which it refers as the basis of its claims or objections, except as provided by law; each party bears the risk of the consequences associated with committing or failing to proceed with it; 2) the court controls the course of the trial; facilitates dispute settlement by reaching an agreement between the parties; clarifies, as necessary, the litigants, their procedural rights and obligations, the consequences of committing or failing to act; assists participants in litigation in the exercise of their rights; prevents the abuse of the rights of participants in the trial and takes measures to fulfill their responsibilities. That is, the competitiveness relations are those civil procedural relations that arise during civil proceedings and are characterized by the parties' proving their positions while facilitating the court's such evidence. In turn, cooperative relationships differ from those of competitiveness in that they can occur not only during the trial, but also before it begins. An example of a civil procedural relationship of cooperation is the pre-trial settlement of the dispute, provided for in Article 16 of the CPC of Ukraine ${ }^{31}$. Another example, the amicable agreement of the parties, is regulated by the norms of Article 207 of the same legal act. Cooperation by means of a settlement agreement is carried out in order to settle the dispute on the basis of mutual concessions. The last highlighted type of civil procedural relationship in the nature of interaction is management relations. An example of such legal relationships is the

30 Цивільний процесуальний кодекс України : Закон України від 18.03.2004 № 1618-IV. Відомості Верховної Ради України. 2004. № 40-41, 42. Ст. 492.

31 Цивільний процесуальний кодекс України : Закон України від 18.03.2004 № 1618-IV. Відомості Верховної Ради України. 2004. № 40-41, 42. Ст. 492. 
enforcement of court decisions provided for in Section VI of the CPC of Ukraine. That is, those relationships in which one party (namely the court) exerts a leading influence over the other parties. That is, such a criterion for the distribution of civil procedural relations should also be agreed.

Depending on the functions and tasks performed, civil procedural relationships are generally classified as regulatory and protective. Civil procedural relationships aimed at the settlement of a dispute involving a judge are regulatory. The largest civil procedural legal relations are of a regulatory nature. For example, civil litigation on pre-trial settlement of a dispute between the parties or civil litigation on litigation involving a judge are regulatory. In turn, protective civil procedural relationships include a number of other civil procedural relationships, including restorative, punitive and compensatory. Examples of restorative civil procedural legal relations are legal relations on renewal of procedural terms, provided by Article 127 of the CPC of Ukraine; legal relations on the resumption of proceedings in the case, regulated by Article 254 of the CPC of Ukraine, etc. Punitive civil procedural relations arise in the case of non-compliance with the subject of judicial prescribing. For example, Article 18 of the CPC of Ukraine ${ }^{32}$ establishes that failure to comply with a judgment is a ground for liability established by law. Witnesses may be brought to participate in punitive civil legal proceedings in the case of knowingly giving false testimony or refusing to give evidence at the request of a court, as evidenced by the provisions of Article 91 of the CPC of Ukraine. The last type of protective civil procedural legal relationship is the compensatory legal relationship. The current CPC of Ukraine provides a number of grounds for the emergence of such relationships. For example, the provisions of Article 51 of this regulatory act indicate that such legal relationships may arise in the event of the defendant being replaced by another defendant. In such a case, the defendant has the right to make a claim for compensation for the legal costs incurred by him as a result of the plaintiff's unjustified actions, which is the basis for the occurrence of compensatory civil procedural relations. Similarly, a witness may initiate civil proceedings for compensation for his expenses related to a subpoena, as provided for in Article 69 (4) of the CPC. That is, in general, we agree with the expediency of allocating such a criterion for the classification of civil procedural relations.

According to the division of rights and obligations between the subjects of civil procedural relations, the latter are divided into one-sided and twosided. Justice in Ukraine is exercised exclusively by the courts, and therefore civil procedural legal relations for the administration of justice are unilateral,

32 Цивільний процесуальний кодекс України: Закон України від 18.03.2004 № 1618-IV. Відомості Верховної Ради України. 2004. № 40-41, 42. Ст. 492. 
since the rights are vested exclusively in the courts. Accordingly, any legal relationship between the court and the parties, between the parties, between the court and third parties, between the parties and third parties is bilateral.

The last distinguished criterion is the presence and nature of interest of the subjects of civil procedural relations. The relations between the court and the persons having a material interest in the results of the case are highlighted; relations between the court and persons having a procedural interest; relations between the court and persons who are not interested in the outcome of the case, but which contribute to the administration of justice (experts, translators, secretary, etc.). The very essence and content of this variety arises from the name of each particular relationship. An analysis of the content of the CPC of Ukraine shows that each of the selected varieties is indeed characteristic of civil procedural relations. Therefore, we conclude that, despite the low level of scientific attention, the existing concept of classification of types of civil procedural relations is relevant.

\section{CONCLUSIONS}

Thus, the study of the system of civil procedural relations revealed a low level of scientific attention to this issue and the presence of theoretical gaps. This institute has come a long way in evolution, and its current state is the result of many years of development. However, after Ukraine's declaration of independence, there is actually no scientific interest in the system of civil procedural relations. To date, there are very few works on this subject, dating from the last two decades. Domestic scientists mostly use the works of Soviet authors in their works. Therefore, today the issue of the system of civil procedural legal relations needs further elaboration, improvement of the conceptual and categorical apparatus, as well as the return to scientific discussions, because the discussions at the time were the same impetus, which significantly contributed to the development of theoretical models of the system of civil procedural legal forms. as it exists now.

Among the existing groups of scientific concepts of determining the institute of civil procedural relations we join a complex (synthetic, universal) group. Civil procedural relations, according to a complex (synthetic, universal) group of scientific concepts, are dynamic multi-stage social relations that arise on the basis of the rules of civil procedural law, have imperative-dispositive character, constitute an individualized social ties between the obligatory subject - the court, and other participants in the civil process, are characterized by the presence of legal rights and obligations that ensure the proper and prompt consideration and resolution of civil cases, and $\mathrm{t}$ takozh fulfillment of court decisions on protection of violated, unrecognized or disputed rights, freedoms and interests of individuals, the rights and interests of legal entities, state interests etc. 
The modern model of the system of civil procedural legal relations is characterized by the following features:

a) civil procedural relationships are regarded as a system of specific, individualized legal relationships that develop in the course of a civil case from its opening to termination;

b) civil procedural relationships form a system of closely interrelated and interrelated legal relationships;

c) the system of civil procedural relations consists of a set of relatively independent legal relationships that differ from each other on the basis of origin, subject composition, content, object;

d) none of the legal relationships that are in the system can exist in isolation from the others.

\section{SUMMARY}

The article deals with the analysis of the definition of civil procedural relations. Investigates the model of "system of civil procedural relations". The author states that today the most appropriate and relevant is the concept - the model of the system of civil procedural relations.

The author examines the features of the modern model of the system of civil procedural relations. Notes that the content of the concept of such a model clearly demonstrates the use of all historical background since pre-revolutionary times. The author provides a classification of civil procedural relations.

The author emphasizes that the system of civil procedural relations is independent and individual for each specific case.

\section{REFERENCES}

1. Васильєв С. В. Цивільний процес України : навчальний посібник. К. : “Центр учбової літератури”, 2013. 344 с.

2. Васьковский Е. В. Курс гражданского процесса. Том 1. Субъекты и объекты процесса, процессуальные отношения и действия. М. : Издание Бр. Башмаковых, 1913. 691 с.

3. Великий тлумачний словник сучасної української мови (з дод. і допов.) / уклад. і голов. ред. В. Т. Бусел. К.; Ірпінь : ВТФ "Перун”, 2005. $1728 \mathrm{c}$.

4. Гражданский процесс : хрестоматия : учеб. Пособие / под ред. проф. М. К. Треушникова. 2-е изд. испр. и доп. М. : ОАО “Издательский Дом “Городец”, 2005. 896 с.

5. Гурвич М. А. Гражданские процессуальные правоотношения и процессуальные действия. В 3-х т. Том 3: Вопросы гражданского процессуального, гражданского и трудового права. М. : ВЮЗИ, 1965. C. $62-116$. 
6. Гурвич М. А. Основные черты гражданского процессуального правоотношения. Советское государство и право. 1972. № 2. С. 29-36.

7. Джалилов Д. Р. Гражданское процессуальное правоотношение и его субъекты. Душанбе, 1962. 72 с.

8. Диденко Л. В. Сущность системы гражданских процесуальних правоотношений. Право и политика. 2015. Спецвыпуск. С. 70-75.

9. Діденко Л. В. Система цивільних процесуальних правовідносин. Visegrad journal of human rights. 2016. № 614. Р. 29-35.

10. Зейдер Н. Б. Гражданские процессуальные правоотношения. Саратов : СГУ, $1965.72 \mathrm{c}$.

11. Кілічава Т. М. Цивільне процесуальне право : навч. посіб. К. : Центр учбової літератури. 2007. 352 с.

12. Мозолин В. П. О гражданско-процессуальном правоотношении. Сов. государство и право. 1955. № 6. С. 50-57.

13. Паскар А. Л. Система цивільних процесуальних правовідносин. Науковий вісник Чернівецького університету. 2011. Вип. 578. С. 83-87.

14.Проблемы науки гражданского процессуального права / [В. В. Комаров, В. А. Бігун, В. В. Баранкова та ін.] ; под ред. проф. В. В. Комарова. Х. : Право, 2002. 440 с.

15. Теоретичні проблеми цивільного процесуального права : підручник / М. М. Ясинок, М. П. Курило, О. В. Кіріяк, О. О. Кармаза, С. І. Запара та ін.; за заг. ред. д.ю.н. професора М. М. Ясинка. К. : Алерта, 2016. $890 \mathrm{c}$.

16. Фурса С. Я. Цивільний процес України: академічний курс : підручник для студ. юрид. спец. вищ. навч. закл. - К. : Видавець Фурса С. Я., КНТ, 2009. 848 с.

17. Цивільне процесуальне право України: підручник для юрид. вузів і фак. / В. В. Комаров, В. А. Бігун, П. І. Радченко та ін. ; за ред. В. В. Комарова. Харків : Основа, 1992. 416 с.

18. Цивільний процесуальний кодекс України : Закон України від 18.03.2004 № 1618-IV. Відомості Верховної Ради Украӥни. 2004. № 40-41, 42. Ст. 492.

19. Чечина Н. А. Гражданские процессуальные отношения. Л. : Издво Ленингр. ун-та, 1962. 68 с.

Information about the author: Didenko L. V., $\mathrm{PhD}$, Associate Professor at the Department of Civil and Economic Law and Procedure, International Humanitarian University 33, Fontanska Road str., Odessa, 65009, Ukraine 